\title{
MIDDLE SCHOOL TEACHERS ATTITUDES TOWARDS THE NEED FOR STUDENT FEEDBACK AND ATTITUDES TOWARDS THE IMPACT OF FEEDBACK ON TEACHERS PROFESSIONAL DEVELOPMENT
}

\author{
Kristi Palk \\ University of Tartu (ESTONIA)
}

\begin{abstract}
Feedback from students is a valuable tool for teachers who based on the feedback get to evaluate their teaching performance and to then plan their work [1] and that is the main reason why the interest in student feedback has been increasing over the last decade [2]. The term "student feedback" refers to students' opinion about the teaching and usually includes students' perception of learning and teaching. It may include descriptions of factors that support learning, as well as out-of-school factors that support learning. The feedback can be collected through interviews or discussions and be anonymous or written feedback [3].
\end{abstract}

Different authors [1], [4] suggest that the value of student feedback has increased significantly as it improves teachers' professional development and is a necessary tool for leading education in the desired direction. Researchers from previous studies [4], [5] find that feedback is increasingly being taken into account when planning work. On the other hand, studies on the same topic with students [2], [6], [7] has shown that students feel their opinion has not been taken into account, and that they often do not get asked for feedback. When feedback was asked then it seemed it was not taken into account.

The purpose of the present study was to identify the middle school teachers' attitudes towards the need for student feedback and to find out their reasoning behind it as well as to find out teachers' views in regards to the impact of feedback on the teachers' professional development.

The empirical part of the qualitative study was carried out using semi-structured interviews with ten middle school teachers. The qualitative inductive content analysis was used to analyze the data.

The current study showed that middle school teachers feel that students feedback is important because it provides them with information about the performance of their work. Teachers also felt that asking students for feedback is important as it improves the cooperation between the students and the teacher. Furthermore, through feedback, the teacher and students become colleagues who make decisions collectively.

The study also showed that feedback was more needed when they were starting to teach and did not have any prior experience of teaching. Also, the interviewed teachers claimed that young students do not provide as helpful feedback as older students and that is why younger student do not get asked for feedback very often. Another outcome of the study showed that although students give honest feedback, the teachers lack the time to ask for it. The study also revealed that teachers feel that they need feedback from students to help with professional development. Student feedback encourages teachers to try new things.

Keywords: feedback from students, the need for feedback, professional development of the teacher.

\section{INTRODUCTION}

Feedback from teachers is important to students, whose emotional state, motivation and attitudes towards assignments and learning are dependent on teachers' feedback [8]. Student feedback on the other hand is important to teachers who based on the feedback can evaluate their performance as teachers, plan their work [1] and develop professionally [9]. In this article, the term "student feedback" is referring to students' opinions about teaching that includes descriptions of factors that support learning and factors that do not support learning. The feedback from students is collected either by having a one-to-one conversation with a student about teaching methods, as a group discussion, or in writing given anonymously or non-anonymously [3]. Previous studies on attitudes towards student feedback has shown that teachers have both positive [10], [11], [12], [13], and negative [10], [14] 
attitudes towards students' feedback. Positive attitude goes together with more positive attitude towards evaluating process and being open to changes in teaching and going along with modern teaching [10], [15]. Negative attitude comes from the belief that the grades have a strong impact on the students' feedback [14]. Negative grades would impact student's ability to give objective feedback and is therefore seen as a revenge on teacher. On the other hand, a study with students has shown, that students worry a lot about how not to offend the teacher when giving feedback. There were students who said they don't want to hurt the teachers' feelings [2]. Researchers have also found that teachers do not consider the students to be competent enough to give feedback towards teaching [14]. A study on students found, that in their opinion the teacher who does not ask for the feedback is considering themselves to be more superior to the students and believe themselves to know better when it comes to the needs of the students than the students themselves [2]. This study aims to identify the middle school teachers' attitudes towards the need for student feedback and to find out their reasoning behind it as well as to find out teachers' views in regards to the impact of feedback on the teachers' professional development.

\subsection{Theoretical Background}

According to teachers, asking feedback regularly is necessary for both the learner and the teacher and without asking feedback there cannot be targeted learning [16]. Different studies indicate that student feedback is requested for various reasons. The main purpose for asking feedback is to inform the teacher about their teaching methods effectiveness. In addition, the students' feedback is providing information about the quality of teaching to the staff [17], [18].

In a previous study [5] in higher education has pointed out that university's lecturers attitude is a determining factor in the use of student feedback. If the university lecturers are having a positive attitude towards students' feedback, then they are willing to make changes in their course based on the received feedback. Also, the teachers who value student feedback fine that student feedback is helping them to improve their teaching skills and to develop professionally as a teacher [19]. In a study with middle school teachers it turned out that a third of teachers asked feedback from students in order to make teaching more effective, and took students' opinion and proposals into account when planning studies ahead [20].

In a previous research [10], [18] about teachers' attitudes it turned out that although teachers' overall attitude towards student feedback is positive and teachers value the feedback received from students, they do not make changes in their teaching based on feedback collected from students. From a study conducted in England that investigated how teachers asked students for feedback, it turned out that, despite the students' lack of experience in offering suggestions to the teacher, students had plenty of teaching-related suggestions [2].

In a study conducted in Estonia that investigated a formative assessment, the teachers pointed out that students should be taught to provide feedback and those students who have been practicing giving feedback are giving feedback in an adequate and supportive way [16].

As previously mentioned, student feedback is especially valued by beginner teachers who thought, that students provide reliable and useful feedback and student feedback is having a positive impact to their work satisfaction. In addition, the teachers find that they need more student feedback because there is room for improvement in their professional skills and they are more precarious in their teaching [4]. Some however, thought that students do not have much to say about teaching and lesson planning [14]. A previous research also found that teachers who are more experienced do not want to change their teaching methods [18].

Earlier studies [2], [21] with students have shown that students like to be asked for feedback by teachers. Asking feedback from students shows to them that the teacher cares about their opinion and that the teacher wants to understand the students. Students on the other hand thought that they could provide teachers with useful information about learning and teaching. A study conducted by the general education school leaders revealed that they did not see the need or opportunity to make the decision-making process more democratic in the school and the involvement of the entire team, so they did not see the value in student or staff feedback [22]. The involvement of the entire team, including the students, in the decision-making process, however, is characteristic of democratic school organization [23].

According to different authors, the reliability or quality of the feedback depends on number of factors. Previous studies [16], [20] performed in Estonia with teachers and students, revealed that the age of 
students was considered important factor in order to be able to give reliable feedback. Teachers found that especially younger students give more positive feedback [16]. Many teachers agreed that feedback from students is reliable in assessing the quality of teaching and in designing quality enhancements, but there are also teachers and educational institutions where students' feedback is not taken seriously enough. One of the main problems is the interpretation of feedback which can lead to false understanding. Another problem is the institutional structure that makes teachers give grades more easily in order to get more positive feedback, because getting negative feedback indicates, that the teacher is not doing a good job at teaching. The third problem is the publication of feedback in school website that is seen for all school staff and students. Teachers have negative attitudes of reviling students feedback in public, because it brings humiliation and negative emotions rather than improvement in teaching skills. The focus should be on the students' perspective and the correct understanding of it, not on evaluating teachers [15]. In a study that summarized the general conclusions from the research on student ratings the most common misconceptions about student feedback were that students cannot make consistent judgments because their young mind is variable. Another myth was that students' ratings are just popularity contests and students want easy courses. The teacher that entertains students and lets them of easily gets better feedback. Furthermore, another myth was that students' ratings are unreliable and invalid. On the latter mentioned myth the study says that it ignores more than 50 years of credible research on the validity and reliability of student ratings. The same study claimed that in general student ratings are reliable and valid [17].

The professional development of a teacher is necessary to be competent enough to analyze the feedback he or she receives [24], but there are evidence, that collected feedback from students is not often used to improve teaching quality. Only few teachers pointed out that they made major changes to their teaching practice and methods based on feedback from students [18]. By emphasizing student feedback to a student teachers' we could possibly make future teachers appreciate the feedback more [25].

The reflection shows the teacher the past work results and criticizes past behavior and creates a vision of how to make work more effective in the future [26]. It is suggested that self-assessment is an evaluation of the results and activities that will reveal the strengths and weaknesses of the teacher. While analyzing teachers work it is important to get feedback from students in regards to whether the selected learning strategies are sufficient for student [27]. The higher the teacher's reflection and selfanalysis skills are the higher goals they are going to set for developing their competence [28]. Reflective practices are giving teacher a change to make better use of students' feedback. Through collecting student feedback, the learning becomes a process of exchange and teacher is developing better relationships with their pupils [25]. During the reflection, the teacher analyses their experiences and uses students feedback to get more information. The value of reflection is based on the perception that it is always possible to get better on a professional level trough reflection. In previous studies [1] the teachers pointed out, that they know their students' opinions without asking their feedback, so they do not need the students to give feedback. On the other hand, they understand they need to improve their teaching skills but do not know how to ensure their professional development.

In summary although student feedback is important for both students and teachers, teachers' attitudes towards student feedback can be either positive or negative and that for various reasons. Valuing feedback determines the extent to which it is used to make teaching more effective. According to teachers the reliability of student feedback depends on a variety of factors, such as the age of students giving the feedback and the myths about student feedback. Feedback, however, is considered essential by both students and teachers. Students see the importance of feedback in sharing useful information with teachers regards to teaching methods and teachers consider student feedback to be important as it supports teachers' professional development.

Based on the theory, the aim of this study was to identify the middle school teachers' attitudes towards the need for student feedback and to find out their reasoning behind it as well as to find out teachers' views in regards to the impact of feedback on the teachers' professional development. This aim was approached with the following research questions:

1 How do teachers describe their attitudes regarding feedback from students and what was their reasoning for their attitudes?

2 What, in their view, would be the impact of feedback from students on their professional development? 


\section{METHODOLOGY}

The present study used a purposeful sampling [29] and criteria for the participants was that they were teaching in middle schools (7-9 grade). The subjects were selected on the principle that no more than two teachers would be interviewed from one school. Participants were contacted by e-mail. Ten female teachers from five southern Estonian towns participated in the study. The background data of the participants can be found in table 1. on the following link: http://lingid.ee/1iUKU

The data was collected using semi-structured interviews. In this way, it was possible to develop a targeted conversation and move away from the rigorous question-answer survey [30]. A semistructured questionnaire was developed based on research questions and previous studies [1], [4], [5], [6], [7]. According to the research questions, two thematic blocks were formed: teachers' attitudes towards feedback from students with explanations about their attitudes and the assessment of teachers' feedback on the need for professional development. Each topic block contained two main questions and further clarifying additional sub-questions. The full questionnaire can be found in table 2. on the following link: http://lingid.ee/T94jU

First, an interview questionnaire was prepared, and then a pilot interview was conducted with a participant who was fitting the criteria set by the author of this work, to verify the comprehensibility of the questions and the relevance of the research questions and whether all the research questions will be answered. The findings from the first pilot interview proved to be inadequate and were not used in the data analysis of this work. A second pilot interview was carried out on the revised interview questionnaire, followed by no changes to the questions plan, the data was used in the data analysis.

For qualitative analysis, a qualitative inductive content analysis method was chosen, which is suitable for subjective interpretations and analysis of text data through a systematic coding and arrangement process [31]. The analysis took place in various stages. The data analysis consisted of three steps: transcription of the interviews, coding, and categorizing [32]. The formation of categories can be found in table 3. on the following link: http://lingid.ee/Kb2Tq

The researcher was keeping a diary during the research process in order to increase the reliability of work and to get an overview of the progress of the work [33]. In addition, a co-coder was included to the work, who encoded one interview completely. Both encoded interviews were then compared and the differences in codes were discussed and reached a consensus.

\section{RESULTS}

The aim of this study was to investigate the middle school teachers' attitudes towards the need for student feedback, to find out their reasoning behind it and to find out what impacts student feedback may have on the teachers' professional development. The findings described under each research question and are supported by quotations from the interviewees.

\subsection{Attitudes towards the need for student feedback and with explanations}

\subsubsection{Positive attitudes toward students' feedback}

The teachers who participated in the study pointed out a number of aspects that creates a positive attitude towards student feedback. According to the participants the teacher receives feedback about the quality of teaching. The teachers pointed out that it is important to find out whether the students understand the teacher or not. They also pointed out that there are aspects that teachers do not think of themselves about their teaching methods and therefore it is important for students to be able to express their opinions about what is methodically suitable for them and what is not. The study showed that through student feedback the teacher gets information about whether they are doing a good job, and student feedback is a direct indicator of the quality of teacher's work. According to the participants the feedback provides confirmation that students have understood what they were taught.

Feedback is needed because without it you can't be a hundred percent sure that everyone understood what was being taught (Kärt).

The participants mentioned that asking students for feedback helps to improve the cooperation between the teacher and the students. Also asking feedback helps to improve the relations between the teacher and the students and it helps the teacher to fit in with the class. The teachers pointed out that feedback from students enriches the teacher-student interaction and helps the teacher to achieve 
better engagement with the classroom. Asking for feedback will show students that the teacher considers them to be equal partners.

For me, feedback is very important in the sense that it just helps to ease into that class and shows that you are not above the students, but you are a tool for the students to acquire knowledge. Asking students for feedback will definitely help me to be accepted by the students (Kärt).

The teachers indicated that mostly students want to give feedback and giving feedback is important to students, because it makes them feel that they are a part of the learning process. Teachers mentioned that students sometimes give feedback even when they are not asked for feedback, but in most cases the students do not give feedback on their own initiative.

The student will not automatically get the idea to give feedback, the teacher has to realize, that something is wrong and ask for feedback (Kersti).

The participants feel that students are competent enough to give feedback based on their experience with different teachers. According to the teachers, feedback can be asked from students of all ages, because when a teacher is competent enough one can give meaning to all kinds of feedback. For example, if students pointed out that a lesson was boring, or another lesson was interesting then students can also explain the aspects that caused boredom or made the lesson interesting. It was pointed out that middle school students are able to comment on the methodology that teacher the uses and make suggestions about the teaching methods, because they have experience with the teaching methods of other teachers.

Students gave very justified feedback and I take it very seriously. For example, when a student writes that I spoke too fast, then I admit that it is quite true as I tend to hurry (Karin).

The teachers in the study pointed out that feedback from students is reliable because students in their opinion are honest. Teachers think that students are honest in giving feedback both publicly and anonymously. Students in the teachers' opinion are happy to give straightforward and honest feedback because they do not expect that giving feedback could be harmful to them. It also came out that if a student has a trusting relationship with a teacher, then the student will give more honest feedback as he is certain that he will not be subjected to punishment or disapproval.

Middle school students do not really think about what the teacher might think about the feedback that the students are giving, and because of that they give honest feedback (Kersti).

\subsubsection{Negative attitudes towards students' feedback}

The teachers who participated in the study also pointed out a number of aspects that creates a negative attitude towards student feedback. They pointed out that if a teacher is wasting lesson time on collecting feedback then that teacher will not have enough time to go through the compulsory material. The teachers thought that other teachers who allow students to give feedback will do so at the expense of important topics of compulsory material. The teachers said that asking students for feedback is a waste of time, because students do not develop more communication skills by giving feedback.

During a long period of being a teacher I have seen teachers that speak off their lessons by letting students talk and argue, but it all goes on at the expense of important lesson topics (Tiiu).

The study found that teachers do not want to receive feedback from students if the feedback is constantly negative and offensive. The teachers pointed out that some students just want to get revenge on a teacher for disciplining them, so they do not read the students feedback. It was said that experienced teachers are offended by student feedback because the participants believe that experienced teachers are more confident with their teaching methodology and they do not want to make changes to it. It was also pointed out that those teachers who do not ask students for feedback do not want to hear the students' opinions.

If students constantly giving negative feedback, then it tends to form an opinion that I don't care what the students are thinking, and I don't even bother to ask them (Kersti).

Among the teachers there were those who believed that students do not want to give feedback. The participants said that to students it is not important to give feedback, but to receive enough recognition from their teacher. It was mentioned that in the teachers' opinion the students do not want to waste 
any time on giving feedback, because it would come at the expense of good results in their studies as they would have less time to focus on lesson topics.

Students aren't interested in being satisfied with the lesson in long term, they want the teacher to be satisfied with their work and they want to receive enough appreciation (Tiiu).

Some of the teachers who participated in the study felt that the students feedback is not important to them. They mentioned that student feedback was more important to them when they were starting to work as teachers. Now they believe that a teacher with more experience can get feedback without asking it. There were teachers that believed that it is not important to be satisfied with all the lessons and that it must be made clear to students. The teachers said that the students do not need to concentrate on being satisfied with the lessons, but being more satisfied their contribution and activities during the given lesson. It was brought out that also a person in real life cannot be satisfied with all the work they may have to do, and it is not important to always be satisfied. Also, there were opinions that if the teacher asks for feedback too often, then the students start to think that they need to be satisfied with everything that is going on in the classroom.

The fact that one lesson is a little bit less interesting than the other is not at all very important and this should be made clear to the children in early ages. We cannot be satisfied with every task that we are given, and nor should we be (Tiiu).

The teachers pointed out that the student feedback is not reliable because the students are not competent enough to evaluate the work of the teacher. Teachers described that in their opinion the teacher should make the decisions about the teaching methods, rather than to expect that students to give advice about the teaching methods. The teachers considered the students to be honest in their feedback, but the feedback itself do not give any useful information to teachers, because the feedback can be judgmental, rather than constructive. The teachers mentioned that if a student says, for example, that the lesson is boring, then it does not give any valuable information to the teacher.

Some students may be very honest and say that they do not like art at all. While, I'm glad they gave have an honest answer they still have to do it, because there is a program and a curriculum and there is nothing to do. So really there is also nothing to do with this kind of feedback (Helin).

The teachers described that sometimes students are scared to give honest. The participants feel that students are often afraid to give negative feedback in either oral or written form. The teachers feel that as students get older they will learn to predict what kind of feedback the teachers are waiting for. It was also pointed out that sometimes students do not want to give feedback because they are afraid of the reactions of the teacher or classmates.

They give very detailed feedback, but sometimes they are even scared to give feedback, for example, one student didn't dare say that he didn't have a pencil, they have such fears that prevent them from giving feedback or talking about their misfortunes. I think that there may be various reasons for it, for example, the fear of classmates, that can't understand, or a sad experience with another teacher maybe (Helys).

The interviewees also found that feedback from students is not reliable because the students want to get revenge on their teachers It was said that if there are students in the class who need to be continuously disciplined, then this student's feedback is likely to be negative. According to the teachers, some pupils give negative feedback because of a trot and they desire to get a revenge on the teacher. It was said that students can give unreliable feedback because they know that the teacher can't to anything to stop them and that there will no consequences as a result

There are some teachers, who say that they don't read the annual school feedback because the students are trying to get revenge on the teachers (Kersti).

\subsection{Professional development}

\subsubsection{Provides an input for analysing teachers' work}

The participants presented different aspects of analyzing feedback based on the professional development of a teacher. They described that useful student feedback for professional development is constructive and free from judgement. According to the teachers it is important that feedback is specific and provides plenty of suggestions, and includes thoughts that the teacher would not normally think of themselves. Also, the teachers thought that a competent teacher can get enough feedback 
from the students' body language. On the other hand, the teachers believed that the students should be taught how to provide feedback and teachers should learn from other teachers, who are collecting feedback, how to effectively gather feedback. It was suggested that it would be useful to observe a colleagues' lesson, to learn from them about their feedback collecting methods in order to develop their own feedback collecting skills. The teachers also described how they make any collected feedback useful to themselves. They described that they write down the ideas that are often repeated, then they summarize the feedback received and then they discuss the results with the students in order to make sure they get the correct conclusions from the feedback.

It might be possible for teachers to watch the lessons of those colleagues' that are collecting feedback in order to see what this feedback requesting looks like (Kärt).

From the point of identifying the teacher's developmental needs, the interviewees had the opinion that feedback is more necessary for the inexperienced teachers, who may not have sufficient selfconfidence in their professional development and want continuous confirmation that their chosen method is appropriate. The teachers believe that, in order to identify a teachers' professional developmental needs, students need to be asked to provide feedback about the tasks, the comprehensibility of the questions, and the clarity of the explanations, because the teacher may not be able to see incomprehensible aspects of the learning materials and teaching methods. The participants mentioned that feedback allowed the teacher to know how to organize the learning process so that students would be satisfied. The teachers described that is not enough to read through feedback once and then throw it away. The teachers felt that it is important to analyze feedback and draw conclusions from it. According to the participants the teacher must understand the reasons why the feedback is as it is. The teachers believe that only through the analysis, a teacher can act on the feedback.

If you get feedback as a teacher, you can think through it so that you can show the material to the majority as they would like you to. Then the students will see, that they have a little say as well (Kärt).

\subsubsection{Provides an input for direct changes in teachers' work}

The teachers who participated in the study revealed a number of aspects in feedback based changes in their work. They mentioned that they would make changes in their teaching if they felt that the feedback received was fair and objective. Teachers claim that they have also made changes in their behavior based on students' feedback. For example, they have changed the way they communicate with their students. In one instance it was described that students gave feedback by saying that the teacher was screaming in lessons and, based on that feedback, the teacher has tried to speak more quietly with the students. The teachers also described that they have made methodological changes. For example, some teachers have tried to be more patient with the students and not to move forward with topics without consulting the students.

The teacher can change the things that students didn't like, if she thought that the feedback was fair and objective (Tiiu).

Describing the changes based on student feedback, the interviewees also described the impact of not doing any modification to the teachers work. Teachers felt that if the feedback from students is collected by school with standard questionnaire, the results do not provide a good understanding of students' opinions. For example, same teachers said that at the same time there were students, that asked for more homework, and students that asked for less homework. The teachers feel that based on this kind of feedback there cannot be implemented any changes. On the other hand, the teachers found that if a teacher does not develop methodically and do not apply changes in teaching then the teaching methods will become routine and boring for the students.

If the teacher stays with the same methods and he does not change them at all, then he will become boring for the students. They already know and can prepare for them and give the teacher signals that are useful to them (Tiiu).

\section{CONCLUSIONS}

The aim of this study was to identify the attitudes of middle school teachers about the need for feedback from students, to find out how teachers explain their attitudes and to find out the teachers' point of view about the impact of feedback on the teachers' professional development. 
The following is a summary of some of the main learnings. The results of the current study reveal that in developing an attitude towards students feedback it is critical whether the teachers consider the feedback to be reliable or not. Positive attitude towards student feedback is related with considering the feedback to be reliable and more negative attitude is related to considering the students feedback to be unreliable. Recent studies have shown that the teacher's attitude towards student feedback determines the way in which teachers use the feedback [5] and the more the teachers believe that collecting student feedback helps them to improve professionally, the more student feedback they will collect [19]. Similar results have been found in other studies [10], [14], [15] which have shown that if a teacher has a positive attitude towards student feedback and they consider that feedback to be reliable then they are more open to students' suggestions [5], [15]. On the other hand, if a teacher has a negative attitude towards student feedback than that teacher also considers students feedback to be unreliable and that students are not competent enough to give feedback. The author of this article suggests that one way to make student feedback more valuable to teachers it to prioritize more student feedback at the time when the teacher is starting their career. This would potentially increase the chance that in the future the teachers would view students' feedback as a source of reliable information.

The interviewees mentioned that the importance of student feedback relied on giving teachers information about teaching and also improving cooperation between the teacher and the students. Recent studies [4], [5], [10], [19] have found that student feedback offers important information about the quality of teaching. The author of this article feels that based on various studies, there is sufficient evidence that students provide reliable feedback, and the feedback can be useful for the teacher in planning their work and making teaching more effective. But still there are teachers that point out a lack of time as an obstacle in collecting student feedback. In the teachers' opinion the students do not want to waste any time on giving feedback, because it may come at the expense of lower results in their studies because there would be less time to focus on lesson topics. On the other hand, some teachers pointed out that asking for feedback does not have to be time consuming, there is enough time to ask feedback for a few minutes in every lesson. On the opinion of the author of this article it is important to ask student feedback although working as a teacher can be intensive and it may seem to teachers that asking feedback can take a lot of time. By asking for feedback the teacher does not have to wonder about the needs of improvement, because the student feedback is already providing information about it. A recent study [19] have shown that teachers want more feedback from students if they believe that the feedback is useful to them and that it supports their professional development. The current research pointed out that for some interviewees the student feedback is not considered reliable because they had an opinion that the students are trying to get a revenge on teachers by giving negative feedback. It was said that if there are students in the class who need to be continuously disciplined, then this student's feedback is likely to be negative. Similar results have been found in recent studies [14], [20], that indicate that the teachers feel that students get revenge on a teacher by giving a negative feedback. Also, researchers have found that teachers do not consider the students to be competent enough to give feedback about teaching. The author of this article feels that a negative feedback is also needed and valuable in supporting teachers' professional development. For example, if the feedback from students actually includes negative feedback from a student that the teach knows is out for revenge, the teacher can analyze why the student felt this way. The author considers that it could be possible to prevent conflicts by constantly asking for student feedback and knowing the students' suggestions about teaching.

The results of the study also revealed that according to teachers, feedback for professional development can be useful and constructive when it is free from judgement. It is important for the interviewees that the feedback is specific, provides plenty of suggestions and includes thoughts that the teacher did not come up with. Also, the teachers thought that a competent teacher can get enough feedback from a students' body language. In recent study [1] with teachers pointed out that the teachers also felt that the student feedback is useful for professional development, but on the other hand the teachers said, that they do not know how to ensure their professional development, although they understand that they need to improve their teaching skills.

The author of article believes that the teachers think that they know the students' opinions based on previous experiences in similar situations, but without asking students, one cannot be sure of the students' opinions. For example, a teacher might assume that students do not want to have homework and prefer the schoolwork to be done during lessons, but when students are asked for feedback about it, it turns out that there are also those students who still want to work at home to expand their knowledge. So, without asking for feedback it cannot be known. 
The results of the current study reveal that teachers that are more experienced, find the students feedback offensive because they have improved their methods for many years and they do not approve of the criticism about their work. There were also teachers who claimed that students' opinions did not really matter, because in real life students would never be satisfied with every assignment and that it must be taught to students from early on that it does not matter. Recent studies [5], [15] also claim that in the teachers' opinion the student feedback cannot be trusted because students are not competent enough to give feedback. In recent studies [2], [21] the students feel that teachers do not appreciate feedback from students.

In the opinion of the author the students and their perceptions are changing over time and therefore, one cannot believe that once the teacher has identified the opinions of the students then there is no need to collect student feedback in the future. Asking feedback from students should be taking place, no matter how much experience the teacher may have. Unfortunately, there were interviewees in the current study that felt the need for student feedback only when they were just starting out as teachers and now that they are more experienced they feel that there is no need to collect student feedback. A recent study [4] with teachers showed also that one of third of beginner teachers felt the need for professional development and for student feedback. Out of the more experienced teachers only $20 \%$ admitted that they have room for professional development. Asking for student feedback is of high importance to both new teachers and to more experienced teachers because there is always an opportunity to develop professionally.

\section{REFERENCES}

[1] K. Edström, "Doing course evaluation as if learning matters most." Higher education research \& development, vol. 27 no. 2, pp. 95-106, 2008.

[2] B. Morgan, "I think it's about the teacher feeding off our minds, instead of us learning off them, sort of like switching the process around': pupils' perspectives on being consulted about classroom teaching and learning." The Curriculum Journal, vol. 20 no. 4, pp. 389-407, 2009.

[3] L. Harvey, "Student feedback [1]." Quality in higher education, vol. 9 no. 1, pp. 3-20, 2003.

[4] B. Jensen, A. Sandoval-Hernandez, S. Knoll \& E.J. Gonzalez, "The Experience of New Teachers: Results from TALIS 2008." OECD Publishing. vol. 2, rue Andre Pascal, F-75775 Paris Cedex 16, France, 2012. Retrieved from https://eric.ed.gov/?id=ED530796

[5] T. N. Beran \& J. L. Rokosh, "Instructors' perspectives on the utility of student ratings of instruction." Instructional Science, vol. 37 no. 2, pp. 171-184, 2009.

[6] Lastekaitse Liit, Kokkuvõte uuringust: Laste ja noorte osalus ja kaasamine koolis [Summary of the survey: Participation and involvement of children in the school], 2014. Retrieved from http://www.eetika.ee/sites/default/files/www_ut/laste_ja_noorte_osalus_ja_kaasamine_koolis_0. pdf

[7] H. M. Chain Anderson \& E. Bird, "Online student course evaluations: Review of literature and a pilot study." American Journal of Pharmaceutical Education, vol. 69, no. 1, pp. 5, 2005.

[8] T. N. Zacharias, "Teacher and student attitudes toward teacher feedback". RELC journal, vol. 38, no. 1, pp. 38-52, 2007.

[9] M. Huxham, P. Laybourn, S. Cairncross, M. Gray, N. Brown, J. Goldfinch \& S. Earl, "Collecting student feedback: a comparison of questionnaire and other methods." Assessment \& Evaluation in Higher Education, vol. 33, no. 6, pp. 675-686, 2008.

[10] F. Nasser \& B. Fresko, "Faculty views of student evaluation of college teaching." Assessment \& Evaluation in Higher Education, vol. 27, no. 2, pp. 187-198, 2002.

[11] L. P. Schmelkin, K. J. Spencer \& E.S. Gellman, "Faculty perspectives on course and teacher evaluations." Research in Higher Education, vol. 38, no. 5, pp. 575-592, 1997.

[12] T. Beran, C. Violato, D. Kline, \& J. Frideres, "The utility of student ratings of instruction for students, faculty, and administrators: A "consequential validity" study." The Canadian Journal of Higher Education, vol. 35 no. 2, pp. 49-70. 2005.

[13] N. Entwistle \& P. Ramsden, “Understanding Student Learning” (Routledge Revivals). Routledge, Croom Helm, 2015. 
[14] J. Douglas \& A. Douglas "Evaluating teaching quality." Quality in Higher education, vol. 12, no. 1, pp. 3-13. 2006.

[15] J. T. Richardson, "Instruments for obtaining student feedback: A review of the literature. Assessment \& evaluation in higher education," vol. 30, no. 4, pp. 387-415. 2005.

[16] M. Jürimäe, A. Kärner \& K. Lamesoo, "Kujundava hindamise projekti l etapi uurimistulemuste aruanne" [Report of the formative assessment design evaluation research project] Tartu: Haridusuuringute ja õppekavaarenduse keskus. 2011.

[17] S. L. Benton \& W. E. Cashin, "Idea paper\# 50 student ratings of teaching: A summary of research and literature." 2012

[18] D. Kember, D. Y. Leung \& K. Kwan, "Does the use of student feedback questionnaires improve the overall quality of teaching?" Assessment \& Evaluation in Higher Education, vol. 27, no. 5, pp. 411-425, 2002.

[19] P. Runhaar, K. Sanders \& H. Yang, "Stimulating teachers' reflection and feedback asking: An interplay of self-efficacy, learning goal orientation, and transformational leadership." Teaching and teacher education, vol. 26, no. 5, pp. 1154-1161, 2010.

[20] I. Unt, "Õpetajate ja õpilaste otsustamisvõimalustest koolielus. E-S. Sarv (Toim), Osalusdemokraatia toimimisest Eesti üldhariduses [Teachers and students' decision making in school life." E-S. Sarv (Toim), The functioning of participatory democracy in general education in Estonia], pp. 39-55, Tallinn: TLÜ Kirjastus. 2008.

[21] K. Kollo, "Põhikooli õpilaste suhtumine füüsika õppimisse ja õpetamisse" [Primary school students' attitudes towards physics learning and teaching] Bachelor thesis. University of Tartu. 2015.

[22] H. Heinla, "Üldhariduskoolide direktorite nägemus õpetajate, lapsevanemate ja õpilaste otsustamisvõimalustest koolielus. E-S. Sarv (Toim), Osalusdemokraatia toimimisest Eesti üldhariduses" [General Education School Leaders Views About Teachers, Parents and Students Decision Making in School Life] Tallinn: TLÜ Kirjastus. 2008.

[23] D. Sabia, "Democratic/utopian education." Utopian Studies, vol. 23, no. 2, pp. 374-405, 2012.

[24] S. M. Brookhart, "Feedback that fits. Engaging the whole child: Reflections on best practices in learning, teaching, and leadership," pp. 166-175. 2008.

[25] M. Z. Iqbal, M. Ramzan \& A. A. Arain, "Students' Feedback: A Stimulus Reflective Practice for Professional Development of the Prospective Teachers." Journal of Research \& Reflections in Education (JRRE), vol. 10, no. 1, 2016.

[26] S. Izumi-Taylor, Y. Y. Lee, D. Moberly \& L. Wang, "Reflective Skills of Pre-service Teachers: a cross-cultural study of American and Japanese college students." Research in Comparative and International Education, vol. 5, no. 2, pp. 131-143, 2010.

[27] K. Pajus \& H. Voolaid, "Õppetunni läbiviimise metoodika ja õppetunni analüüs" [Analysis of the Methodology and the lessons in conducting lessons] Haridus- ja Teadusministeeriumi välishindamisosakond, 2013.

https://www.hm.ee/sites/default/files/oppetunni_labiviimise_metoodika.pdf

[28] K. Poom-Valickis, "Novice teachers' professional development across their induction year" Doctoral dissertations. Tallinn's University, 2007.

[29] A. Hardon, C. Hodgkin \& D. Fresle, "How to investigate the use of medicines by consumers." World Health Organization and University of Amsterdam. Switzerland: Amsterdam. 2004.

[30] S. Hirsjärvi \& H. Hurme, "Tutkimushaastattelu," IV. Helsinki: Yliopistopaino. 2006.

[31] H. Hsieh \& S. E. Shannon "Three approaches to qualitative content analysis" Qualitative health research, vol. 15, no. 9, pp. 1277-1288. 2005.

[32] P. Mayring, "Qualitative Content Analysis." Forum: Qualitative Social Research, vol. 1, no. 2, 2002. Retrieved from: http://217.160.35.246/fqs-texte/2-00/2-00mayring-e.pdf.

[33] J. W. Creswell \& D. L. Miller. "Determining Validity in Qualitative Inquiry. Theory in Practice," vol. 39, no. 3, pp. 124-130. 2000. 